\title{
CROWD CONTROL Can our public order police still deliver?
}

Bilkis O mar, Institute for Security Studies

bomar@issafrica.org

From the heavy-handed crowd control under apartheid to the abusive actions of the Internal Stability Division during the early 1990s, public order policing in South Africa has been steeped in controversy. However, things changed after 1994 when this component of the police was radically transformed. With a decline in demand for their specialised services, and a need for more resources, the units have been reorganised into Area Crime Combating U nits (ACCUs). W hile no doubt helping to reduce crime, it is unclear whether the SAPS still has the capacity to manage the increasing number of volatile crowd situations.

S outh Africa's transition to democracy in 1994 brought about many changes. For policing, this meant transforming from repressive apartheid-style policing to a police service willing to serve the people. Given the role played by the Internal Stability Units (ISU s) under the previous government, these units were in need of a major overhaul. Their central function at that time was "the enforcement of apartheid laws, the suppression of political unrest and the prevention of unrest, intimidation and unrest-related crimes". ${ }^{1}$

This article provides a brief update on the status of the public order police units after $1994 .^{2}$ The units have undergone many changes over the years to accommodate the demands of the times. Initially the apartheid stigma needed to be expunged. More recently, the growing number and intensity of service delivery protests and riots, and the poor handling of some of these events, have highlighted the need to reassess the effectiveness of our public order policing capacity.

In their current form - the Area Crime Combating Units (ACCUs) - the key question is whether South Africa has the capacity to manage public events and protest marches, particularly when they are accompanied by violence or the threat of violence.

\section{Pre 1994: Focus on political unrest}

The 1960s in South Africa were notable for the absence of riot control units. According to Rauch and Storey this can be attributed to the banning of political parties and the imprisonment of political leaders. ${ }^{3}$ As a result there were fewer public protests against the apartheid regime, which reduced the need for these units. When problems did arise, local police members, together with the military, were tasked to control the unrest. With no specialised police training or units, the consequences were dire when violence did break out at public events.

The 1970s saw the revival of the resistance movement against the state, necessitating the South African Police (SAP) to develop its riot control capacity. By the 1980s the SAP had formed a somew hat established riot control unit that focused on averting and restraining crowds.

The early 1990s saw an increase in political activity in South Africa, which brought many challenges for the riot control units. The various marches and rallies that characterised the era could not be managed as was done previously. After several incidents, such as those at Sebokeng in 1990 and Daveyton in 1991, the government realised that the 
role and function of the riot control units in perpetrating violence had to be addressed.

A National Peace Convention was held on 14 September 1991, resulting in the $N$ ational Peace Accord, "the purpose of which was to bring an end to political violence in [the] country and to set out the codes of conduct, procedures and mechanisms to achieve this goal". ${ }^{4}$ The signatories to the Accord had to agree to a code of conduct for political parties and organisations, as well as for police officials something that up to this point was absent in the police. Chapter 6 of the Accord addressed the issue of public gatherings. ${ }^{5}$ It called for a commission of enquiry into the prevention of violence and intimidation.

As established by the Prevention of Public Violence and Intimidation Act of 1991, the purpose of the Commission was "to investigate and expose the background and reasons for violence, thereby reducing the incidence of violence and intimidation". ${ }^{6}$ The Goldstone Commission was tasked with this investigation in O ctober 1991. The objectives of the Commission were to:

- inquire into the phenomenon of public violence and intimidation in the Republic, the nature and causes thereof, and what persons were involved therein;

- inquire into any steps that should be taken in order to prevent public violence and intimidation;

- make recommendations to the State President in respect of public violence or intimidation. ${ }^{7}$

In the interim, the SAP management had decided that the police and the army (which had been providing limited assistance in dealing with public unrest), needed to concentrate on their primary functions, namely crime prevention and defence respectively. This led to the formation of the Internal Stability Division (ISD) in 1992. The ISD's main function was the "policing of unrest through proactive (preventive) and reactive measures and the prevention of crime in unrest-plagued areas". ${ }^{8}$ It comprised 36 Internal Stability Units that were deployed in ten regions. ${ }^{9}$

The Goldstone Commission in the meantime had come up with several recommendations for the President with regard to steps to prevent violence and intimidation:
- deploying an effective police presence in local communities;

- utilising the new division of Internal Security to counter violence;

- taking urgent steps to prohibit the carrying of dangerous weapons in public; and

- improving the relationship between the police and local communities. ${ }^{10}$

The Goldstone Commission also recognised the necessity to legislate public gatherings, given the forthcoming democratic elections. The outcome was the Regulations of Gatherings Act 205 of 1993. The Act aims "to regulate the holding of public gatherings and demonstrations at certain places; and to provide for matters connected herewith". ${ }^{11}$ The basic premise of the Act is that every person has a right to peaceful participation in gatherings - with the protection of the police. This was a significant step for public policing in South Africa.

In the meantime the ISD had become very unpopular and controversial due to its paramilitary manner; to the extent that critics began calling for the demilitarisation of the units. ${ }^{12}$ According to $\mathrm{N}$ gubeni and Rakgoadi, the powers and functions of the ISU $s$ were so broad that the police were implicated in cases around the abuse of power (through using their discretionary powers), misconduct, and intimidation of community members. ${ }^{13}$

\section{Post 1994: Public order policing takes shape}

After 1994 a new approach was needed to policing in South Africa - one that would serve the new government and the people. Thus began the transformation of the police from a 'force' into a 'service' that would protect the rights of all South Africans to equality, dignity, freedom and security, as entrenched in the Constitution. ${ }^{14}$ These were qualities notably lacking in South African policing.

Part of the transformation process entailed bringing the SAPS in line with international policing standards. Fortunately, substantial financial as well as technical assistance was made available from several countries for this purpose. This helped in developing a 'restructuring strategy' for the SAPS, and especially the ISD. In the case of public order policing, the restructuring process was far-reaching and entailed 
reselecting and retraining members within a two-year period, shrinking the public order component from 10,000 to 7,000 members, and most challenging of all, attempting a mindset change among members who were accustomed only to repressive methods of policing. The end of 1995 saw the ISD and the Riot Control U nits of the so-called homeland police merge under the new SAPS.

In 1997, a SAPS policy document was introduced which emphasised crowd management as opposed to crowd control. The goals of the public order police as set out in the document are precise and simple:

- to establish standardised procedures in the SAPS to manage crowds in such a way that these conform to democratic values and accepted international standards;

- to install an approach in POP, concurrent with SAPS values, of acting at all times in a professional, acceptable and an effective manner, in a way that is community orientated and to be accountable for every action - based on certain constitutional principles;

- to accomplish ideals for crowd management situations - relating to life, property, citizen satisfaction of police and feelings of safety at gatherings, and risks to SAPS personnel;

- to perform all tasks effectively and efficiently. ${ }^{15}$

Also detailed in the document are the 'principles of intervention' that should govern crowd management. This section deals with the legal aspects, the situational appropriateness of the gathering, the optimisation of equipment and personnel, and the proportionality of the means of force to be used. The document also discusses preparation for operations, command and control, and coordinating and operational committees. Also covered are the use of force, the role of the media, the role of the South African National D efence Force (SANDF), traffic departments and other emergency services.

After some debate, the policy was eventually adapted into Standing O rder 262 on Crowd Management during $G$ atherings and Demonstrations, applicable to all operational members of the SAPS. ${ }^{16}$ The purpose of the Standing Order, introduced in 2002, is "to regulate crow $d$ management during gatherings and demonstrations in accordance with the democratic principles of the Constitution and acceptable international standards". ${ }^{17}$ The O rder contains much about community partnerships and communication with the public, signifying the police's move towards a more community-oriented approach.

\section{From 'public order' to 'crime combating'}

SAPS management first considered the transformation of the public order units into Area Crime Combating Units (ACCUs) in 2001. This implied a role reversal for the units, with their primary focus becoming crime combating and prevention rather than public order and crowd management.

The decision to review the units' mandate and form the ACCUs was based on the decrease in the number of public protests with the demise of apartheid and the inception of the new government; and the new Public Finance Management Act 1 of 1999, which demanded 'value for money' budgeting. ${ }^{18}$ All this came at a time when crime levels were increasing, and the SAPS was in search of more resources in line with its new National Crime Combating Strategy (NCCS).

The NCCS was launched in 2000 as a "high density, cordon, search and seizure operation to combat crime in hot-spots most affected by crime" ${ }^{19}$ Its principal innovation was a rigorous focus of police attention on the 140-odd police stations in which half of all crime in South Africa is recorded. On 13 June 2002 the M inister of Safety and Security, Charles N qakula, stated:

All POP units are being transformed into ACCU s that will conduct intelligence-driven operations that require high force levels. Examples of these will be parallel roadblocks on highways and secondary routes, and cordon and search operations. This is intended to deal with bank robberies, cash in transit heists and the hijacking of vehicles, as well as taxi and gang violence. ${ }^{20}$

W hile on the face of it the formation of the ACCU s appears to have diminished the main purpose of the specialised public order policing unit, a counter argument is that the change makes financial and 
operational sense, given the shortage of capacity within the police and the escalating crime problem facing the country at the time. ${ }^{21}$

\section{Roles and responsibilities of ACCUs}

The document establishing the ACCU s determines their roles and functions within the various levels of government. Its goal is "to maintain public order by combating serious and violent crime, policing public gatherings, rendering specialised operational support to other units/components/divisions and ensuring effective information management". ${ }^{22}$

Before 1994 the public order units were centralised, with orders and instructions coming from police headquarters in Pretoria. After 1994 the units were decentralised to provincial level. With the establishment of the ACCUs, the units have been decentralised even further to area level, although they can be deployed on an area, cross-area, and provincial basis.

\section{Command and control}

Command and control of the units is delegated to area level and is coordinated by the ACCU commander who reports to the deputy area commissioner responsible for operations and uniformed policing. Public order policing responsibilities at area level include:

- ensuring the effective and efficient functioning of the unit in terms of capability, capacity, skills and resources;

- ensuring that ACCU members are deployed in accordance with area priorities;

- ensuring an effective information gathering process that focuses on serious and violent crimes on a continuous basis;

- providing all support services (finance, logistics and human resource management); and

- ensuring that regular evaluations are conducted.

At provincial level, the head of operational response services is responsible for developing ACCU policies, procedures and standards, including the implementation, monitoring and evaluation thereof. While day-to-day deployment is controlled at area level, the provincial commissioner can instruct on any provincial operations relating to public order policing.
At national level, the ACCU s fall under the divisional commissioner of operational response services, who provides national strategic direction to maintain public order. The office also develops, monitors and evaluates national standards, policy and procedures. ${ }^{23}$

In essence, this means that SAPS head office provides the strategic direction for public order policing, while the provincial departments deal with policy, standards and monitoring. It is the area level that arguably matters the most because this is where the functioning and day-to-day activities of the ACCUs are handled.

\section{Selection and training of members}

ACCU commanders are selected by the responsible officers at national and provincial levels. The members of the units are selected at provincial and area level, together with the area commander of the ACCU. Table 1 illustrates the numbers of ACCU members based in each province.

Table 1: Number of operational ACCU members, February $2006^{24}$

\begin{tabular}{|lr|}
\hline Gauteng & 1,695 \\
\hline Kwazulu-Natal & 1,255 \\
\hline Eastern Cape & 789 \\
\hline North West & 653 \\
\hline Western Cape & 610 \\
\hline Free State & 537 \\
\hline Limpopo & 399 \\
\hline Mpumalanga & 275 \\
\hline Northern Cape & 114 \\
\hline Head office, Pretoria & 3 \\
\hline Total & 6,330 \\
\hline
\end{tabular}

Source: SAPS O perational Response Services, Pretoria

Training policies are developed at the national office. In-service training is organised at provincial level and conducted by a trainer allocated to each ACCU at area level. Potential ACCU members have to undergo in-service training in crowd management techniques and tactical intervention to ensure that they have the required skills. All operational members have to undergo in-service 
training annually in order to maintain high standards and keep up with current tactical developments.

ACCU members and their equipment also have to be continually assessed by head office to ensure that they are operationally competent. The document establishing the ACCU provides guidelines for the implementation and evaluation of ACCU s. In terms of evaluations, the ACCU commander must conduct at least one inspection every month and at least three detailed inspections annually. ${ }^{25}$

Key operational issues

Planning for ACCU operations is based on the information gathered by the Area Crime Combating Forum. After relevant crime information has been analysed and requests from police stations for upcoming crime combating operations reviewed, operational plans are drawn up.

Although this process allows for ACCU s to participate in crime combating operations, their function is not to supplement stations with additional personnel for day-to-day activities. The ACCU document is clear on this: "The aim of these units is to participate in planned intelligence-driven, crime-combating operations in support of stations". ${ }^{26}$

The above discussion has shown that the necessary policies on ACCU training, equipment, and operations are in place. But the key question is whether these policies are being correctly implemented. O ne of the concerns is that the gradual decentralisation of control over public order policing has resulted in members not being appropriately trained and equipped. Whereas in the past the national division had a hands-on approach to public order policing in the country, the formation of the ACCU means that police at area level are now responsible for the success of the units.

An even greater concern relates to command and control of members during crowd situations. This has, since the formation of the ACCUs, been complicated by the fact that ACCU members have to execute their functions in cooperation with station-level officials who lack specialised training in public order policing. This is likely to result in injuries and fatalities among members of the public during highly volatile situations, as evidenced by the Ellis Park soccer disaster of $2002^{27}$ and the Harrismith municipal protest of $2005 .{ }^{28}$

At Ellis Park 43 supporters died and 158 were injured when chaos erupted at a soccer match at the stadium. A commission of inquiry was set up to investigate the reasons behind the disaster. The commission's report listed 14 reasons for the tragedy - among them the "slow reaction" of the public order police, and a "gaseous irritant" teargas used by these police. ${ }^{29}$

In $\mathrm{H}$ arrismith a 17-year-old boy died after police opened fire to disperse a protesting crowd on the $\mathrm{N} 3$ highway. Twenty youths were shot with birdshot and buckshot. Video footage shows that the police opened fire indiscriminately on demonstrators as they slowly crossed the N 3 highway and then continued firing at them as they fled for cover. No report by the Independent Complaints Directorate (ICD) or the police has yet been released on the incident. ${ }^{30}$

\section{Can the ACCU deliver?}

Great strides have been made with regard to the crowd management unit of the police since 1994. How ever, whether the more recent changes have been for the benefit of public order policing remains to be seen. The key question now is whether the SAPS can still effectively respond to and manage volatile crowd situations.

While the most recent ACCU document on crowd management may be well intentioned, it is not clear that implementation is going according to plan. Responsibility for the effective functioning of the units ultimately rests with police management at area level. These officers must ensure that ACCU members have regular training in crowd management, that equipment is upgraded and kept relevant, and that morale and fitness levels remain high.

Even if this is achieved, a broader question relates to the fact that crime prevention has become the units' primary activity. Already the effects of neglecting the crowd management function and relying too heavily on ordinary police officials for public order policing, can be seen in the poor handling of recent public events. 
O ne of the reasons cited for making crime prevention the units' primary function was the decrease in the number of public marches and demonstrations. However, this trend is changing. Public protest is on the increase again in South Africa given the problems of poverty and poor service delivery, especially at local government level. In the last few years there has been an upsurge of community dissatisfaction over municipal service delivery, with people protesting shortages of housing, lack of sanitation, and water and electricity. $O$ ther issues such as Metrorail's transport problems, ${ }^{31}$ have also led to increased incidences of public protest.

The $\mathrm{H}$ arrismith and M etrorail incidents are two among many that indicate the need for interventions by specially trained and experienced public order policing units. Structured as they are currently, there is a danger that the units will be deprived of their specialist abilities. Perhaps the most imminent challenge in this regard is the soccer World Cup in 2010.32 ACCU members will have to be trained to deal with soccer hooliganism and related security issues. A fitness standard for operations has to be established, and given that the current average age of a SAPS ACCU member is 35 years, ${ }^{33}$ and that the World Cup is still four years away, the age policy of the units has to be revisited by area commissioners.

The changes to public order policing in South Africa over the past 40 years have been necessary and warranted, given the shift in the country's politics and legal framework. Police management has also responded to the challenges facing the post-1994 society by adjusting the structure and mandate of the public order policing units. However, given the increase in public protest and rioting in the last few years, it is likely that the current capacity and effectiveness of the ACCUs will need to be revisited.

\section{Endnotes}

1 J Rauch and D Storey, The Policing of Public Gatherings and Demonstrations in South Africa 1960 1994, Centre for the Study of Violence and Reconciliation, Johannesburg, 1998, <http://www.csvr.org.za/papers.papjrds>, p 1.

2 The methodology for this paper was mainly desktop research in addition to interviews with a few stakeholders.

3 J Rauch and D Storey, op cit, p 3.

4 National Peace Accord, <http://www.incore.ulst.ac.uk/ services/cds/agreements/pdf/sa4.pdf>, p1.

5 Ibid, pp 26-32.

6 Ibid, pp 26-27.

7 Ibid, pp 27-28.

8 D M eyer, The South African experience in dealing with communal violence, African Security Review 8(1), Institute for Security Studies, 1999, $<$ http://www.iss.org.co.za/pubs/ASR/8no1/The SouthAfrican exp.html>p 7.

9 Ibid, $\mathrm{p} 7$.

10 National Peace Accord, $p 6$.

11 Government of SA, Regulation of G athering Act 205 of 1993.

12 See paper by K N gubeni and S Rakgoadi, Transforming the Internal Stability U nit, 1995, <http://www.csvr.org.za/articles/artknsr.htm>, pp 1-2.

13 Ibid, p 2.

14 The Constitution of the Republic of South Africa, chapter 2, p 7.

15 SAPS, Approved Crowd Management Policy: Public O rder Police (POP), 1997, p 5.

16 Telephonic interview with Supt V Day, 11 November 2005.

17 SAPS Standing O rder 262 on Crowd Management during Gatherings and Demonstrations, $\mathrm{p} 1$.

18 SAPS Policy: Division: O perational Response Service: The Establishment and Functioning of Area Crime Combating Units (ACCUs), 2004, p 1.

19 N edbank ISS Crime Index 2(4), 2000, p 7.

20 Budget Vote for Safety \& Security, 13 June 2002.

21 See Criminal Justice Monitor, N edbank ISS Crime Index 1(4), 2000, p 1.

22 SAPS ACCU Policy, op cit.

23 Ibid.

24 The numbers are not inclusive of civilian and support services personnel.

25 SAPS ACCU Policy, op cit.

26 Ibid, $\mathrm{p} 7$.

$27<$ <http://www.iol.co.za/general/ newsview.php?art_id=20020927>.

$28<$ <ttp://www.news24.com/N ews24/ South_Africa/N ews/0,,2-7-1442_1693754,00.H tml. http://www.news24.com/N ews24/South_Africa/N ews/ 0,6119,2-7-1442_1584092,00.html>.

29 Ibid.

30 The trial is still pending according to the $\mathrm{N}$ ational Director: O perational Response Services, Director Gibson, interview on 3 March 2006.

31 Commuters set fire to a Metrorail train in Pretoria in 2001 after trains were delayed. <http://www.numsa.org.za//printpage.php?id=796>.

32 South Africa is the host country of this event in 2010.

33 Interview with Supt V Day, 28 February 2005. 